\title{
STUDY ON COMFORT EVALUATION METHODS OF DIFFERENT WOMEN'S HIGH-HEELED SHOES BASED ON ELECTROENCEPHALOGRAPH (EEG) TECHNOLOGY
}

\author{
Xiangdong LUO ${ }^{1 *}$, Sun YUN ${ }^{1}$, Chaohua XUE ${ }^{1}$, Zongmin YUE ${ }^{2}$, Huijun REN ${ }^{2}$ \\ ${ }^{1}$ College of Art \& Design, Shaanxi University of Science and Technology, Xi'an, Shaanxi, P. R. China 710021 \\ ${ }^{2}$ College of Arts \& Sciences, Shaanxi University of Science and Technology, Xi'an, Shaanxi, P. R. China 710021
}

Received: 29.08.2019

Accepted: 12.03 .2020

https://doi.org/10.24264/Ifj.20.1.1

\section{STUDY ON COMFORT EVALUATION METHODS OF DIFFERENT WOMEN'S HIGH-HEELED SHOES BASED ON ELECTROENCEPHALOGRAPH (EEG) TECHNOLOGY}

ABSTRACT. The 24-27-year-old women with 230-235 mm feet with the similar level of education were selected for the study. During the test, those subjects were tested by SD semantic differential measurement method and BP EEG signal acquisition system. The brain electrical rhythm characteristics and the subjective comfort feelings in the states of static standing and uniform natural walking were tested. The experimental results show that the heel mechanical changes caused by the heel height and the motion states are negatively correlated with the $\alpha$ wave intensity of the brain while the subjective comfort evaluation is negatively correlated with the $\alpha$ wave intensity in the parietal and occipital regions. The research results reveal that EEG technology is used to evaluate the comfort of wearing high-heeled shoes, which can not only make up for the lack of the subjective evaluation method, but also improve the comfort evaluation system of wearing shoes and boots. All these have the important theoretical and practical significance for the footwear comfort evaluation.

KEY WORDS: high-heeled shoe, comfort, plantar pressure, electroencephalograph (EEG)

\section{STUDIU PRIVIND METODELE DE EVALUARE A CONFORTULUI ÎN CAZUL PURTĂRII PANTOFILOR DE DAMĂ CU TOC ÎNALT UTILIZÂND} ELECTROENCEFALOGRAFIA (EEG)

REZUMAT. S-au selectat pentru studiu femei în vârstă de 24-27 de ani cu lungimea labei piciorului de 230-235 mm, având un nivel de educaţie similar. Subiecţii au fost supuşi unor teste precum diferenţiala semantică (SD) şi achiziţia semnalului BP EEG. S-au testat caracteristicile activităţii electrice a creierului şi senzaţiile subiective de confort în statică şi în mers natural uniform. Rezultatele experimentale arată că modificările mecanice ale călcâiului cauzate de înălţimea tocului şi de mişcare sunt corelate negativ cu intensitatea undei $\alpha$ a creierului, în timp ce evaluarea subiectivă a confortului este corelată negativ cu intensitatea undei $\alpha$ în regiunile parietale şi occipitale. Rezultatele cercetării dezvăluie faptul că tehnologia EEG este utilizată pentru a evalua confortul în cazul purtării pantofilor cu toc înalt, compensând nu doar lipsa unei metode de evaluare subiectivă, ci şi îmbunătăţind sistemul de evaluare a confortului la purtarea pantofilor şi ghetelor. Toate acestea au o importanţă teoretică şi practică în evaluarea confortului încălţămintei.

CUVINTE CHEIE: pantof cu toc înalt, confort, presiune plantară, electroencefalograf (EEG)

\section{ÉTUDE SUR LES MÉTHODES D'ÉVALUATION DU CONFORT DE DIFFÉRENTES CHAUSSURES À TALONS HAUTES POUR FEMMES BASÉES SUR LA TECHNOLOGIE ÉLECTROENCÉPHALOGRAPHIQUE (EEG)}

RÉSUMÉ. Des femmes âgées de 24 à 27 ans avec une longueur de jambe de 230 à 235 mm ont été sélectionnées pour l'étude, avec un niveau d'éducation similaire. Les sujets ont subi des tests tels que le différentiel sémantique (SD) et l'acquisition du signal BP EEG. Les caractéristiques de l'activité électrique du cerveau et les sensations subjectives de confort pendant une démarche naturelle uniforme et en statique ont été testées. Les résultats expérimentaux montrent que les changements mécaniques du talon causés par la hauteur du talon et le mouvement sont corrélés négativement avec l'intensité de l'onde $\alpha$ du cerveau, tandis que l'évaluation subjective du confort est corrélée négativement avec l'intensité de l'onde $\alpha$ dans les régions pariétale et occipitale. Les résultats de la recherche révèlent que la technologie EEG est utilisée pour évaluer le confort de chaussures à talons hauts, compensant non seulement l'absence de méthode d'évaluation subjective, mais aussi en améliorant le système d'évaluation du confort lors du port de chaussures et de bottes. Tous ces éléments ont une importance théorique et pratique dans l'évaluation du confort de la chaussure.

MOTS CLÉS : chaussure à talons hauts, confort, pression plantaire, électroencéphalographe (EEG)

*Correspondence to: Assoc. Prof. Xiangdong LUO, College of Art \& Design, Shaanxi University of Science \& Technology, No. 6 Xuefu Mid-Road,
Weiyang District, Xi'an, Shaanxi, P. R. China 710021, Tel: +86 13892038335; Email: 326540366@qq.com 


\section{INTRODUCTION}

The comfort of shoes is an important quality factor of shoes, and comfort is currently the subjective feeling of people. Human feet have rich tactile sensations. When wearing shoes, comfort can be described but difficult to quantify. People's subjective feelings cannot be used as a reliable source of comfort evaluation, so relative quantification techniques embody objectively the footwear comfort evaluation.

As an electrophysiological research method, EEG technology has been widely used in the field of comfort evaluation, especially in the research fields of clothing comfort, industrial product comfort and perceptual engineering, and has aroused extensive attention from researchers in the related fields [1].

The comfort evaluation of wearing highheeled shoes is a comprehensive evaluation process integrating multiple feelings. The related indicators of EEG are related to human physiological and psychological aspects. EEG technology evaluation methods can be used for reference in the related fields [2]. Meanwhile, this technology has a physiological and psychological basis for comfort evaluation.

This study applied EEG technology to the comfort evaluation of high-heeled shoes, and explored the method of EEG technology applied to the comfort evaluation of female high-heeled shoes. In the EEG spectra, the features that can best show the comfort of high heels are screened out, and the quantitative relationship between the spectrum signal of the relevant rhythm of the EEG and the comfort of different high heels is obtained.

\section{EXPERIMENT}

\section{Experimental Objects}

The subjects undergoing the EEG tests were required to meet the following criteria:
(1) The subjects had no brain mental illness, and the levels of intelligence development were similar, and they were all right-handed.

(2) The subjects were young women at the age of 24-27 with 230-245 mm feet and they didn't have a long history of wearing the highheeled shoes [3].

(3) The subjects cleaned their hair the day before the tests, and they were forbidden to use oily products, such as hair conditioner and hair oil. The grease and stains would increase the resistance values of the scalps, resulting in the acquisition distortion of the brain waveform.

(4) Empty stomach was prohibited before the tests because studies have shown that hypoglycemia would affect EEG values.

(5) The subjects were revealed the harmlessness of the experiment before the tests so as to eliminate the fear and mental tension of the subjects and reduce the experimental errors.

\section{BP EEG Signal Acquisition System}

The EEG acquisition instruments used in the tests were an American Brainvision Recorder with multi-lead neurotic electrophysiological analysis system consisting of an electrode cap amplifier and a computer display. The software in the EEG equipment was prepared with a Pycoder of the acquisition software and an Analyser of the analysis software before the experiment, and the necessary hardware, software and experimental accessories were prepared. The hardware included a display, an amplifier, and electrode caps while the software included an acquisition software (Pycoder), an analysis software (Analyser), a programming software (E-prime). The accessories contained conductive adhesives, blunt syringes, shampoo, washbasins, hair dryers, towels, slippers. Besides, 6 pairs of experimental shoes with different heel heights were required. 


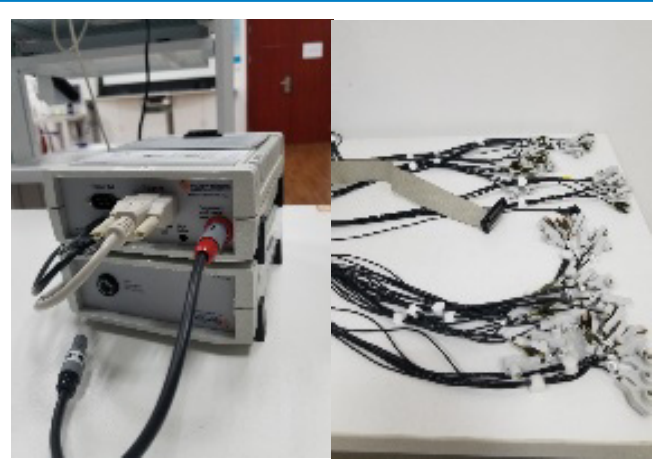

Figure 1. Diagram of the EEG acquisition instrument

EEG is a technique for recording spontaneous rhythmic potentials triggered by stimuli. External stimuli caused the brain to generate potential activity, which was recorded by external electrodes through the human

\section{Experimental Process}

\section{EEG Signal Acquisition}

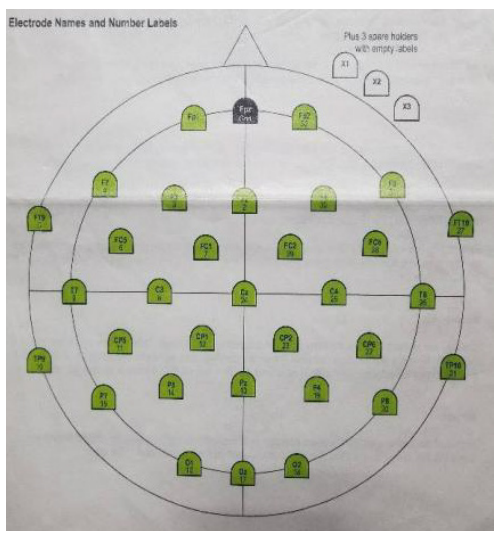

Figure 3. Distribution of the electrode cap test points

Before starting the formal experiment, a set of pre-experiments should be done first. Prior to the start of the pre-experiment, the subjects should read the instructions of the experiment and were told about the precautions of the test process.

(1) The appropriate type of electrode caps was selected for wearing, and then the electrode was positioned based on the center of the parietal region. The electrode placement position was referred to the Placement System

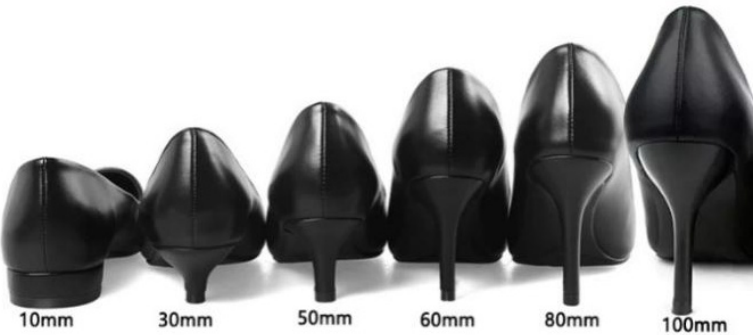

Figure 2. Experimental shoes with different heel heights

tissue to form an electrical signal. The EEG signal amplifier was reached through a junction box. The digital EEG instrument filtered the signals to form the continuous EEG after they were recorded and stored [4].

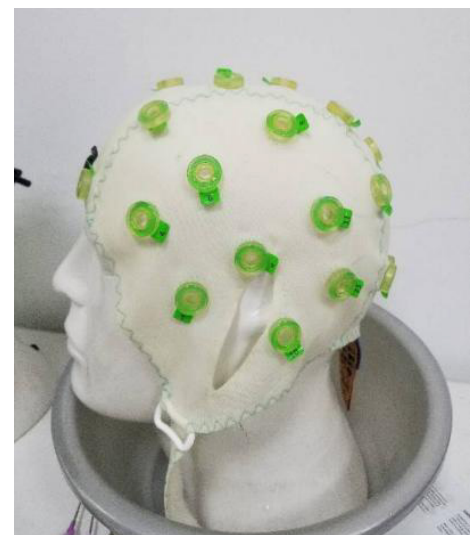

Figure 4. An Electrode Cap

Guide of International 32-lead EEG Electrode. The electrode was comprised of 32-lead locations, wherein the electrode contained a reference electrode, a grounding electrode and 30 position electrodes. 


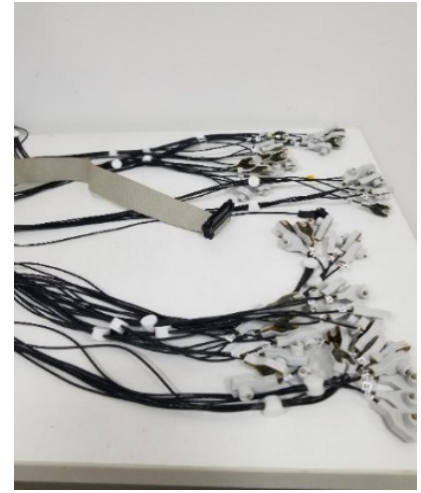

Figure 5. Lead electrodes

(2) The experimental shoes were put on, the electrode cap and the amplifier were connected, and the E-prime was connected to the signal acquisition host. The corresponding experimental shoes were put on to start the experiment. The parameters were debugged and the experimental control parameters were input so as to observe whether the electrode impedance was reduced to less than $5 \mathrm{k} \Omega$.

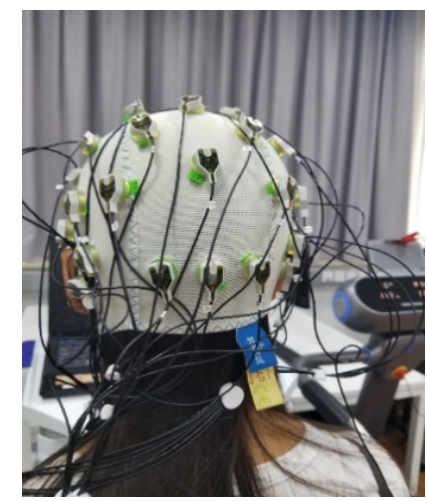

Figure 6. Images of wearing the electrode cap

Four states concerned with the experiment settings and wearing the high heels were studied, which included static standing on the ground with both feet, the left foot standing on one foot, the right foot standing on one foot, and walking with two feet. In order to improve the accuracy of the signal acquisition and reduce the interference of the electromyographic (EMG) signals, the intermission time with different lengths were set after each action.

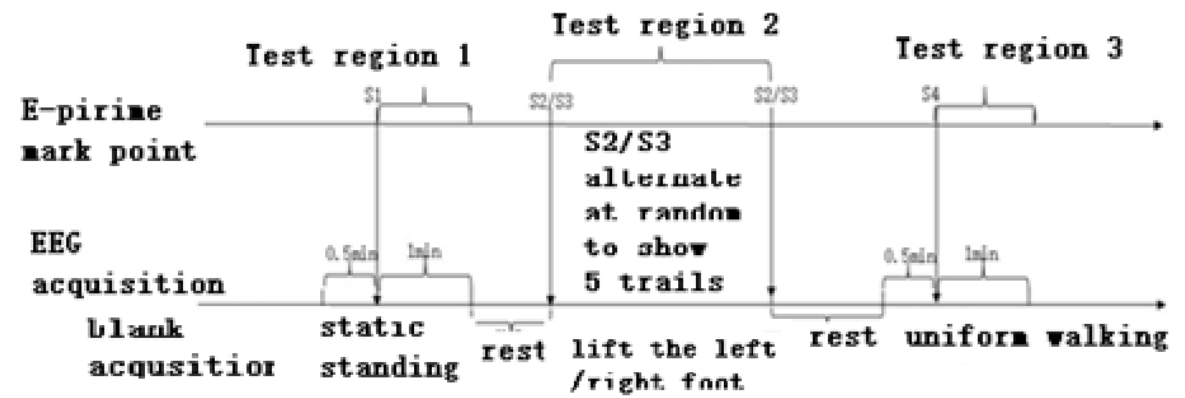

Figure 7. Schematic diagram of test cycle mode

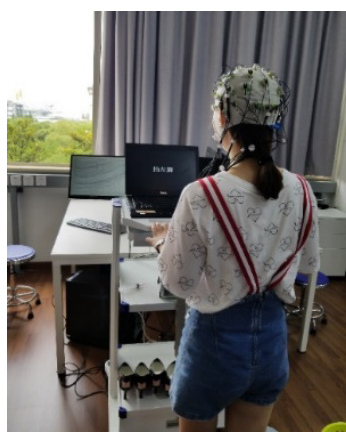

Figure 8. Test image of static standing state

The variables in the experiment were 6 types of high-heeled shoes with different high heels, 3 states of different motions and 32lead electrode acquisition positions [5]. The

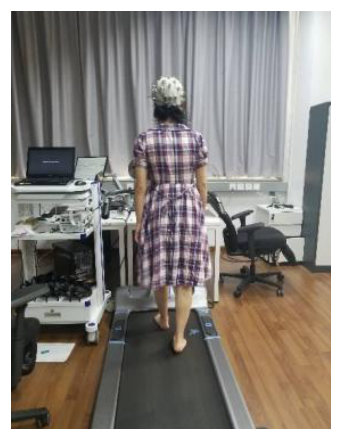

Figure 9. Test image of uniform walking state

signals collected from each subject contained 12 segments. After the acquisition, the names of the subjects plus the numbers of the shoes were labelled individually. 
Subjective Comfort Evaluation

The most common method for the subjective comfort evaluation of wearing shoes and boots was the semantic differential (SD) scale method. Likert scale was used as the scale in the evaluation and five different points were selected.

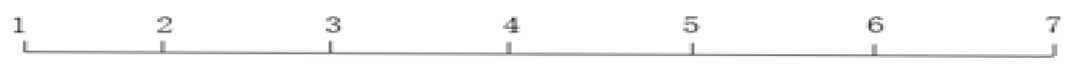
1. strongly uncomfortable;
2. much uncomfortable;
3. somewhat uncomfortable;
4. comfortable;
5. somewhat comfortable;
6. much comfortable;

7. strongly comfortable.

Figure 10. Scoring scales of comfort rating

After having finished the EEG test, the subjects were asked the comfort in the wearing process to evaluate the pre-designed comfort and to score the discomfort sites.

\section{EXPERIMENTAL RESULTS AND ANALYSES}

\section{The Effects of the Heel Heights on $\alpha$ Wave of EEG}

Table 1: Analyses of the effects of the heel heights on $\alpha$ wave power values

\begin{tabular}{ccccccc}
\hline $\begin{array}{c}\alpha \text { wave } \\
\text { power }\end{array}$ & $10 \mathrm{~mm}$ & $30 \mathrm{~mm}$ & $50 \mathrm{~mm}$ & $60 \mathrm{~mm}$ & $80 \mathrm{~mm}$ & $100 \mathrm{~mm}$ \\
\hline static & 17.065 & 17.339 & 16.569 & 16.331 & 14.314 & 12.902 \\
standing & \pm 0.257 & \pm 0.311 & \pm 0.290 & \pm 0.334 & \pm 0.395 & \pm 0.323 \\
uniform & 16.962 & 16.10 & 13.91 & 12.145 & 10.05 & 10.250 \\
walking & \pm 0.071 & \pm 0.425 & \pm 0.003 & \pm 0.539 & \pm 0.022 & \pm 0.417 \\
\hline
\end{tabular}

The average values of $\alpha$ wave of the subjects wearing women's shoes with 10-100 $\mathrm{mm}$ heel heights are statistically analyzed. The experimental results show that both the heel heights and the motion states have the effects on $\alpha$ wave power value. For the 6 different heel heights, all the $\alpha$ power values in the standing state are greater than those in the walking state, which shows that within $1.5 \mathrm{~min}$ of the test, the comfort of wearing women's shoes with all the heel heights in the standing state is greater than that in the walking state. The similar effects of the uniform walking within a short time on $\alpha$ wave also show the restraint.

Table 2: T-test of the $\alpha$-wave paired samples with different heel heights

\begin{tabular}{|c|c|c|c|c|c|c|}
\hline \multirow[t]{2}{*}{ heel height (I) } & \multirow[t]{2}{*}{ heel height $(\mathrm{J})$} & \multirow{2}{*}{$\begin{array}{c}\text { Mean values } \\
(I-J)\end{array}$} & \multirow{2}{*}{$\begin{array}{l}\text { Standard } \\
\text { errors }\end{array}$} & \multirow[t]{2}{*}{ Sig } & \multicolumn{2}{|c|}{$\begin{array}{l}95 \% \text { confidence } \\
\text { interval of difference }\end{array}$} \\
\hline & & & & & Lower limit & Upper limit \\
\hline $10 \mathrm{~mm}$ & $30 \mathrm{~mm}$ & -0.274 & 0.079 & 0.340 & 0.073 & 0.578 \\
\hline $10 \mathrm{~mm}$ & $50 \mathrm{~mm}$ & 0.496 & 0.026 & 0.004 & 0.312 & 0.680 \\
\hline $10 \mathrm{~mm}$ & $60 \mathrm{~mm}$ & 0.734 & 0.096 & 0.007 & -0.485 & 0.551 \\
\hline $10 \mathrm{~mm}$ & 80 mm & 2.751 & 0.204 & 0.000 & -1.215 & 0.509 \\
\hline $10 \mathrm{~mm}$ & $100 \mathrm{~mm}$ & 4.163 & 1.140 & 0.000 & -1.163 & 0.088 \\
\hline
\end{tabular}


Through the $T$ tests of the paired samples, the $30-100 \mathrm{~mm}$ high-heeled women's shoes are used to compare and analyze those flat shoes with $10 \mathrm{~mm}$ heel heights as the most common state of wearing. The results show that there are obvious differences between the four heel heights of 50,60, 80 and $100 \mathrm{~mm}$ and the flatheel heights of $10 \mathrm{~mm}$. The further analysis of variance shows that there are significant differences in $\alpha$ wave values of wearing different heel heights $(P<0.001)$.

The Impacts of Wearing States on EEG
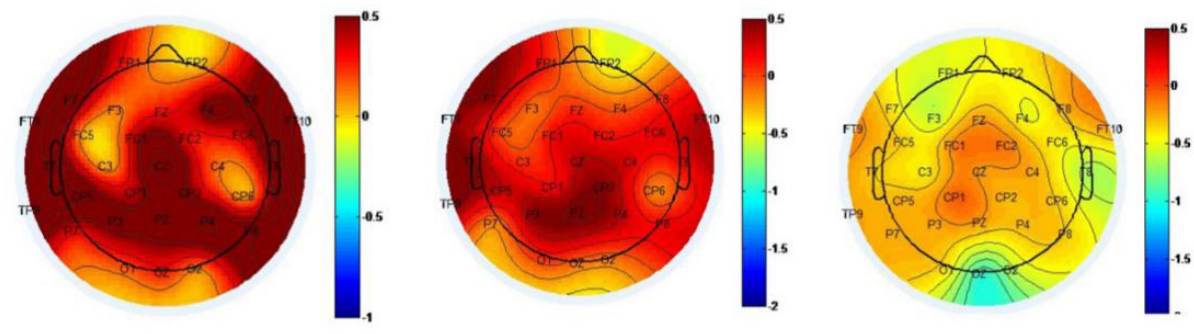

Figure 11. Different BEAMs in the two states

The differential analysis and correlation analysis of the $\alpha$ wave BEAM of wearing the women's shoes with the same height in the standing state and the uniform walking state are respectively performed. In the static standing state and the uniform walking state, the different BEAMs shown in the following are obtained. In the different BEAMs, the deeper the color shows, the greater the differences between the two states are. According to the BEAMs, it can be clearly seen that the differences between the parietal and the temporal regions are most distinct in the following three types of highheeled shoes in the course of wearing.

After obtaining the visual differential results of the regions from the BEAMs, the further accurate correlation analyses are performed on the different motion states of 30 electrodes. Two states can be found to influence the different electrodes on the specific brain regions.

Some channels of EEG are significantly related to the wearing states of high-heeled shoes, and the significant channels include Channels F2, F3, F7, FT9, FC1, T7, TP9, CP5, P7, $\mathrm{O} 1, \mathrm{Oz}, \mathrm{O} 2, \mathrm{P} 8, \mathrm{CP} 2, \mathrm{C} 4, \mathrm{FT} 10, \mathrm{FC} 2$ and P4. There are also some channels that have no significant differences with the motion states in this respect. They are Channels FC5, C3, CP1, Pz, P3, P4, TP10, $\mathrm{CP} 6$, T8 and FC6. By dividing the brain regions with the electrode channels, it is also found that the electrode channels in the parietal region and a small part of temporal region show a strong correlation with the motion states $(P<0.001)$. In addition, the differences between the standing and walking states after comparison and analyses show that in the parietal region, frontal region, and occipital region, the $\alpha$ value of the standing state is greater than that of the walking state $(\mathrm{t}$ $>0)$. Therefore, it can also be concluded that the $\alpha$ wave changes caused by the stimulation of wearing the high-heeled shoes are mainly concentrated on the above-mentioned regions.

\section{RESULTS AND DISCUSSION}

\section{Analyses of the Influences of Heel Heights on $\alpha$ Wave of EEG}

In the related research fields between EEG and emotions, $\alpha$ wave is the most significant brain rhythm in the parietal and occipital regions when the subjects close their eyes, and is also one of the indicators that can be used to reflect the emotional state of the subjects [6]. With negative emotions, such as fear, excitement, anger and discomfort, $\alpha$ waves are restrained. When the subjects wear the higher heels, $\alpha$ waves in their brains are restrained, which proves that the unbalanced pressure distribution of the soles causes the feet and the body to be in an uncomfortable state. Some scholars have used $\alpha$ waves to characterize the comfort in their studies. The percentages of $\alpha$ waves dominating the brain waves are chosen as the study indexes, which are different from those used in the experiment. Although the selected EEG 
indicators are different, the evaluation results on the comfort are consistent [7]. The comfort is related to $\alpha$ waves of EEG. The high-heeled shoes inhibit the appearance of $\alpha$ waves in the course of wearing them, leaving the subjects in an uncomfortable state.

(1) The plantar stress is increased to restrain $\alpha$ waves

The plantar stress under the heels with different heights is different. Some studies have shown that the higher the heel height is, the greater the peak pressure value of the sole is. The peak pressure of the soles in the walking state is stronger than that in the standing state $[8,9]$. Therefore, there is a negative correlation between the spectrum energy of $\alpha$ waves and the peak pressure of the plantar stress. That is to say, the greater the peak pressure of the soles is, the lower the spectrum energy of $\alpha$ waves of EEG is. The smaller the peak pressure value of the plantar stress is, the higher the spectrum energy of $\alpha$ waves of EEG is.

(2) Blood circulation is blocked to restrain $\alpha$ waves

Medical research has shown that the blood circulation system may affect the intensity of EEG rhythm. The blood circulation speed is positively correlated with the fast waves (e.g. $\alpha$ wave and $\beta$ wave) in EEG rhythm [10], but negatively correlated with the slow waves (e.g. $\gamma$ wave) in EEG rhythm. The stress on the body can affect the blood circulation speed. In particular, when the stress on the surface of the skin is too high, the blood circulation system in the human skin is impeded, so the blood flow is decreased, which causes $\alpha$ waves to be restrained. The human foot is the organ full of the capillaries distributed most densely. Therefore, the excessively high local stress on the sole caused by wearing the highheeled shoes can affect the blood circulation of the whole body, thus affecting the $\alpha$ wave intensity.

(3) Mental stress from wearing highheeled shoes restrains $\alpha$ waves

As the height of the heel is increased and the state of wearing the shoes is changed, the mental state continues to strain during the test, causing the mental fatigue. Especially during the process of wearing the heights of 80 and $100 \mathrm{~mm}$, in order to maintain the balance of the body, the subjects are highly stressed to prevent from falling during the test. The constant mental stress may increase the inhibition of the brain's central nervous system to the neuronal activity. Therefore, the thinking activity and complexity in the brain are reduced, and the degree of inhibition of the brain is increased.

Particularly in the standing state of wearing super high heels of $100 \mathrm{~mm}$, although the comfort is reduced, the two feet can still touch the ground so as to keep the body in balance. Once changed in the walking state with this super high heel, the body nervous system is immediately under the state of tension, and the attention is highly concentrated to generate fear. In addition, in order to maintain the body balance, the lower limbs will produce electromyographic signals to interfere the $\alpha$ wave intensity, resulting in the perceived discomfort [11]. In the lower high groups, the difference for this change is not significant. This may be the reason why the mental states of the subjects wearing the lower heels are more stable and the impacts on the brain waves are not obvious.

(4) Mild motion fatigue restrains $\alpha$ waves

Studies have shown that the muscle contraction caused by the motion fatigue brings about the changes of $\alpha$ wave indexes first to rise and then to fall. No matter whether the $\alpha$ wave frequency is increased or decreased, the indexes of $\alpha$ waves are decreased while the energy of $\alpha$ waves is reduced. Therefore, in the course of the experiment of wearing the women's shoes with higher heel heights, the overall experiment shows that the higher height the heels are, the stronger the fatigue of the lower limb muscles is. The muscle fatigue in the walking state is greater than that in the standing state. Changes of the constant muscle contraction affect the degree of excitability of the central nervous system, which reduces the discharge frequency of $\alpha$ waves. The decrease of $\alpha$ wave power values in the course of motion is closely related to the activity between the central neurons. The fatigue caused by walking leads to the brain's inhibitory neurons to be active, which changes the nature of the $\alpha$-fast wave in EEG into other types of slow waves in EEG.

As the heel height is increased from 30 to $100 \mathrm{~mm}, \alpha$ wave intensity presents to decline continuously, which accounts for that the highheeled shoes are of the restrained type no matter 
what state they are in. In the ultra-high heel state, the declining rate is increased, indicating that when the subjects wear the higher heeled shoes, the feelings of "comfort" and "pleasure" are significantly reduced while the feelings of "discomfort" and "tension" are rapidly increased. This is the subject's stress response to his or her body balance, mechanical patterns and mental stress which are beyond their own.

\section{Distribution of Brain Regions Activated by Heel Heights}

The differences of $\alpha$ wave power spectra of six different heel heights under the conditions of 32 electrode channels are individually analyzed. If the order of $\alpha$ wave intensities of each electrode channel is sorted from high to low, regarding the cerebral regions of the brain region as the reference, the brain electrodes are

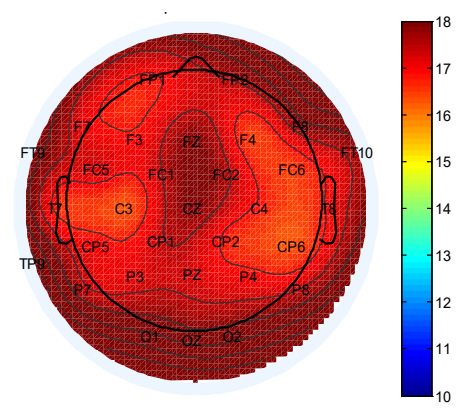

divided into six different regions: $(01 \mathrm{O} 2 \mathrm{Oz} \mathrm{CP} 3$ CP4 CPz), (F3 F4 FZ P3 P4 PZ), (FT1 FT2 FT7 F7 F8), (FC3 FC4 FCZ FT8), (C3 C4 CZ T3 TP7) and (T4 TP8 P7 P). The order from low to high can be obtained as follows: central region < frontal region < occipital region < parietal region. From the following BEAMs, the colors used in different shades indicate the different $\alpha$ wave intensities. It can be clearly seen that the different highheeled shoes and the different motion states have effects on $\alpha$ wave values. The darker the color in the BEAMs, the greater the different $\alpha$ wave intensities in all the channels of the EEG. By comparing the BEAMs of different heel heights and different states, it can be intuitively obtained that the brain stimulation formed from the heel height of the high-heeled shoes and the motion states can activate the brain in the different positions.

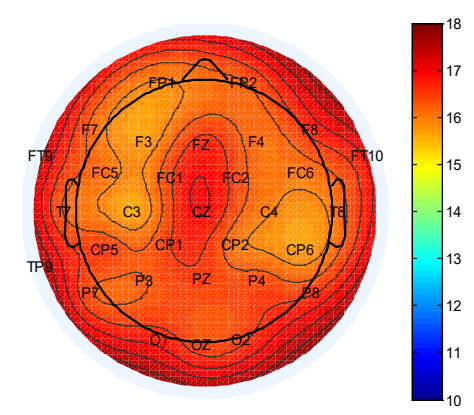

Figure 12. Schematic diagram of $\alpha$ wave intensities in the lead positions

According to the correlation analyses between the BEAMs and the electrode channels in the high activation region, it is considered that the parietal region and the occipital region are the key parts of $\alpha$ wave difference caused by the changes of the heel heights of the women's shoes. The main reasons include three aspects:

(1) The $\alpha$ wave indexes related to the comfort are regarded as a fast wave, which is most obvious in the parietal and occipital regions of the brain. Therefore, the $\alpha$ wave frequency spectrum values collected from these two brain regions are the highest.

(2) The somatosensory stimuli induced by the changes in the plantar mechanics from the variable of heel heights are mainly transmitted through the pressure receptors, while the neural signal transmission analysis and treatment regions of the tactile pressure senses are positioned in the parietal and occipital regions.
(3) As the heel height of the women's shoes is increased, the fatigue caused from the whole test is increased, and the tight nervous system with super high heel of $100 \mathrm{~mm}$ makes the mental fatigue from the subjects increase. Some studies have shown that the mental fatigue can inhibit the activity of the central nervous system, and the excitability of the brain is reduced. There is a strong negative correlation between the mental fatigue and the $\alpha$ wave rhythm.

\section{Relationship between $\alpha$ Wave and the Subjective Comfort Evaluation}

The analytical method of Pearson correlation coefficient is adopted to analyze the relationship between the subjective evaluation results of the stress comfort and the $\alpha$ wave spectrum energy. The correlation analysis is performed between the subjective comfort evaluation results of six kinds of heel heights 
worn by the subjects in the two states, and the $\alpha$ wave intensities of 30 electrode positions.
The results show that the $\alpha$ wave intensity of most lead locations is positively correlated with comfort.

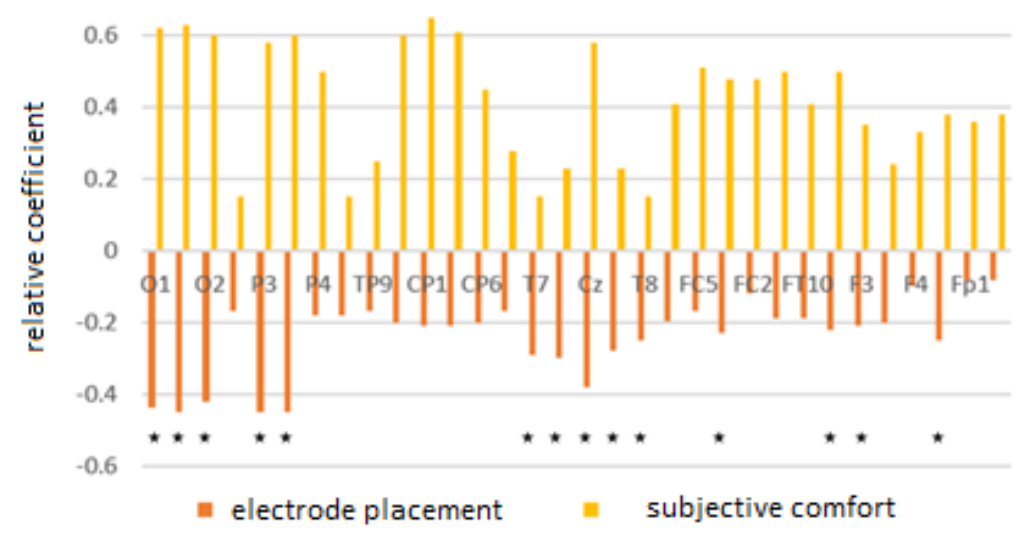

Figure 13. Correlation analyses between the subjective evaluation and the $\alpha$ wave intensity

From the lead position, it can be seen that the $\alpha$ wave intensity measured in most of the brain regions, especially in the occipital region and the parietal region, is much highly correlated with the subjective comfort. The somatosensory stimuli created by wearing the high-heeled shoes include many aspects of psychological feelings, such as comfort on the feet, the stress perception on the soles and the balance of the body. The brain plays an important role in this process.

\section{CONCLUSION}

(1) EEG index $\alpha$ wave can characterize the comfort of women shoes with different heels.

(2) The changes in heel heights have effects on EEG. As the heel heights are increased, the $\alpha$ wave intensity is decreased, but the discomfort is increased.

(3) The brain regions activated by the somatosensory stimuli from wearing the different high-heeled shoes are mainly the parietal region and the occipital area.

\section{REFERENCES}

1. Liu, Y., Chen, D., Wei, Q., Basic Research on Clothing Pressure Comfort Evaluation Method Based on EEG Technology, Jiangnan University, 2016.

2. Chen, D., Zhao, Q., A study on clothing pressure for men's suit comfort evaluation, Int J Cloth Sci Tech, 2007, 15, 5, 320-334, https://doi. org/10.1108/09556220310492598.
3. Lu, Y., Ren, Q., Wu, Y., et al., New advances in electroencephalography, Journal of Modern Electrophysiology, 2014, 21, 2, 125-127.

4. Perry, J., Burnfield, J., Gait Analysis: Normal and Pathological Function, Physiotherapy, 2010, 97, 2, 180-180.

5. Wang, J., Yang, G., Liu, Z., Effects of Different Type of Shoe Soles and Walking Speeds on AEMG of Walki-Related Muscles, Sports Science, 2011, 5, 55-58.

6. Scotti, S., Mauri, M., Barbueri, R., Jawad, B., Mainardi, L., Cerutti, S., Brown, E.N., Villamira, M.A., Automatic quantitative evaluation of emotions in E-learning applications, Proceedings of the 28th IEEE EMBS Annual International Conference, New York City, USA: IEEE, 2006, 1359-1362.

7. Yin, L., Xia, L., Study on Wearing Pressure Comfort Based on Females Physiological Index, Chinese Journal of Ergonomics, 2015, 21, 6, 11-16.

8. Yu, Y., Wang, L., Biomechanical analysis of walking gait, plantar pressure and surface electromyography of young women wearing high-heels of different heights, The 10th National Sports Science Conference, 2015.

9. Cheng, L., Wang, D., Tao, K., Wang, C., Biomechanical characteristics of heels, Journal of Chinese Tissue Engineering Research and Clinical Rehabilitation, 2007, 44, 8944-8947. 
10. Nakahashi, M., Morooka, H., Nakajima, C., Sato, S., Morooka, H., Effects of pressure of pantyhose with controlled loop length on the human circulatory system, Sen'i Gakkaishi, 2003, 59, 10, 77-83, https://doi.org/10.2115/ fiber.59.407.

11. Wang, L., Li, J., Study on sEMG signal changes and fatigue of lower limb muscles in young women walking in high heels, Collected papers of the 10th national sports biomechanics academic exchange conference, Beijing: Zhejiang University, 2002, 372-376.
(C) 2020 by the author(s). Published by INCDTPICPI, Bucharest, RO. This is an open access article distributed under the terms and conditions of the Creative Commons Attribution license (http:// creativecommons.org/licenses/by/4.0/). 